\title{
A Competency Model for Supply Chain Management Professional in the new Era
}

\section{ary \\ * Namita Gupta \\ ** Mridul Dharwal \\ *** Dr Daleep Parimoo}

\author{
Effulgence \\ Vol. 13 No. 2 \\ July - December, 2015 \\ Rukmini Devi Institute of Advanced Studies \\ E-mail : effulgence@rdias.ac.in, Website : www.rdias.ac.in \\ http://effulgence.rdias.ac.in/user/default.aspx \\ https://dx.doi.org/10.33601/effulgence.rdias/v13/i2/2015/40-50
}

\begin{abstract}
Objective - This research studies the impact of Professionalism and Competence for Supply Chain Management in the Capital Goods industry for low cost country like India. The authors have extensively researched the literature and interviewed the professionals from companies with local set-ups as well as leading players worldwide such as GE, BHEL, Alstom, Dresser-Rand, DOOS AN.

Methodology - This is an exploratory study using qualitative research methods. This study aimed at developing a preliminary competence profile for supply chain management professionals, by identifying competency elements based on literature findings. Then the study further aimed at validating \& improving the literature review based SCM professionals profile through the use of probing question methods er getting it confirmed from various focus groups in the target organizations. This finally resulted in a validated industry specific competence profile \& Competency Map document that can be used to map SCM professionals in various roles.

Findings - The supply chain management concept has grown and matured over the last decade due to globalization and has infused varied competencies across this industry as it will continue to evolve in the similar business model diverging across the globe. The emerging critical competencies change as per the roles, for initial level roles focus is on the technical skills such as engineering calculations, manufacturing site operations, contract management, inventory management, competence of meeting global norms and compliances but under a process of time it gives place to the behavioral skills like customer focus, analytical abilities, conflict resolution, excellent communication skills, business acumen, finance and commercial negotiating skills etcfor the higher level roles
\end{abstract}

Future Scope - The research can be extended to larger number of companies in Capital goods industry or further comparative analysis can be conducted for the supply chain managementprofessionals in different industries or at different location of the world.

Limitation - The research is limited to the five organisations in India only hence the identified set of critical competencies of Supply chain professionals cannot be considered to be universally justified. It may vary due to organization specificity, country etc.

Key words : Competency, Supply Chain Management, Capital Goods, Manufacturing industry.

\section{INTRODUCTION}

$\mathrm{I}^{\mathrm{n}}$ the light of the liberalized economy it has become well evident that the success of today's organisations sustainability is dependent on the renewing competencies of its work force. They create a competitive edge that cannot be withered away by any other means. It is well known that for the development of any country's economy capital goods sector is extremely crucial. Primary major reasons of this is that capital goods is considered as a strategic sector and hence development of domestic capabilities is highly essential from a national self-reliance and security perspective, Secondly capital goods sector has multiplier effect and has bearing on the growth of the user industries

\footnotetext{
*Assistant Professor-HR, School of Business Studies, Sharda University

** Assistant Professor- HR, School of Business Studies, Sharda University

***Associate Professor \& HOD-HR, School of Business Studies, Sharda University
} 
as it provides critical input, i.e., machinery and equipment to the remaining sectors covered under the manufacturing activity.

As per the recommendation during the 12th Five Year Plan with a view to achieve $9 \%$ growth in GDP, the manufacturing industry should grow at least by $11 \%$ to $13 \%$ per annum. This implies that the Capital Goods sector, which is considered to be the core of manufacturing, should grow at around $17 \%$ to $19 \%$. The capital goods industry contributes $12 \%$ to the total manufacturing activity (which is about $15 \%$ of the GDP). Keeping the above aspects in mind with respect to the industry it is crucial to know what are the critical dimensions that contribute to success.

Most heavy engineering companies are highly dependent on their strong integrative supply chain as their implementation is on project base. They face challenges in their supply chain on account of the suppliers, production schedule and capacity, logistics and engineering. Above all the Hercules task of maintaining relationships with suppliers to have an optimized and strategic supply base with minimal supply risk takes a toll on the SCM process. Considering the above fact it led the researchers to first start exploring the critical competencies of SCM function.

Supply chain management (SCM) is an integrated function which deals with the acquisition (or procurement) and deployment of goods and services for the department. A supply chain management system must be fair, equitable, transparent, competitive and cost effective. It should provide for at least the following:-demand management, acquisition management, logistics management, disposal management, risk management and regular assessment of supply chain performance along with reporting of supply chain information.

The linkage of supply chain to the management system is explained with the help of the concept of demand-driven value chain. This model has three overlapping areas of responsibility:

- Supply management - Manufacturing, logistics, supply planning and sourcing

- Demand management - Marketing, sales, demand planning and service

- Product management - R\&D, engineering and product development
A system of technologies and processes that senses and responds to real-time demand signals across a supply network of customers, suppliers and employees

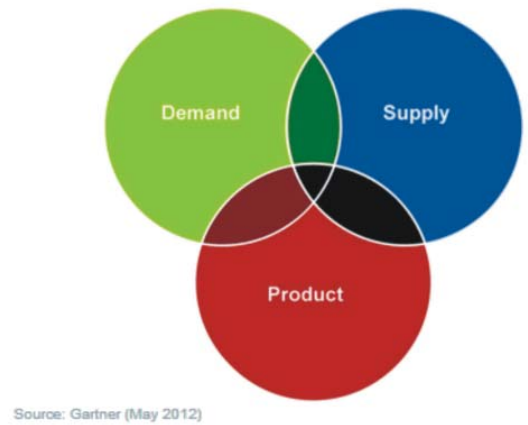

In-order to throw light on the role of SCM competency following elaborations are helpful. SCM competency affects revenue growth through the means of using operational excellence or operational innovation. Operational excellence is "achieving high performance via existing modes of operation," while operational innovation is "the invention and deployment of new ways of doing work" (Hammer 2004 , 86). In this study the researchers are focusing on attaining operational excellence by ensuring the presence of all critical competencies required for the function. Various organisations like Nike (virtual supply chain integration),Wal-Mart (cross-docking), Apple (online product distribution), Dell (order customization) are each well-known for their unique, value-creating SCM competencies.

\section{LITERATURE REVIEW}

As revealed in a Supply Chain Survey 2011 conducted across 62 countries by Business Continuity Institute UK that $85 \%$ of surveyed organisations recorded at least one supply chain disruption in 2011. 40\% of disruption originated below the immediate supplier. As per the analysis of data the facts revealed were highly thought provoking. The summary of it is as pointed below:

1) Supply chain incidents led to a loss of productivity for almost half of businesses along with increased cost of working $(38 \%)$ and loss of revenue $(32 \%)$.

2) Longer term consequences of disruption in the supply chain included shareholder concern (19\%), damage to reputation $(17 \%)$, and expected increases in regulatory scrutiny $(11 \%)$.

3) For $17 \%$ of respondents the financial costs of the largest single incident totaled a million. This figure almost doubles to $32 \%$ where less resilient supply chains are evident in the research. 
Thus it becomes highly essential for a firm to identify its competitive advantage $\&$ thus ensure that it continues to be twined with its core competency \& further cascaded to employees through appropriate competency management process.

According to the management thinker Porter "competitive advantage is at the heart of a firm's performance in competitive markets" he has elaborated on "how a firm can actually create and sustain a competitive advantage in an industry \& how it can implement the broad generic strategies." Thus, competitive advantage means having low costs, differentiation advantage, or a successful focus strategy. In addition, Porter argues that "competitive advantage grows fundamentally out of value a firm is able to create for its buyers that exceeds the firm's cost of creating it." John Kay (1993, pg 14) defines distinctive capabilities as ones derived from characteristics that others lack and which are also sustainable and appropriable. "A distinctive capability becomes a competitive advantage when it is applied in an industry or brought to a market." Kay (p. 194) measures the value of competitive advantage as valued added, with the costs of physical assets measured as the cost of capital applied to replacement costs.

Having considered human resource as an asset creating highly competent team is always at the heart of organizational competitive advantage. It is important to cascade the concept of competency from the organizational end so in-order to do so it is prerequisite to understand the concept of Core competence.

"Core competency" concept was laid out by Gary Hamel and C.K. Prahalad in their seminal article in 1994, "The Core Competence of the Corporation,". Some professionals define companies' core competencies as "the things we need to get right" while others describe them as "the things we do best." Still other executives define a core competency as "the basic skills required to compete in our industry." however, it is interesting to note that Hamel and Prahalad define core competencies as "the collective skills and learning inside an organization that create competitive advantage." In the context of this paper the researchers have considered this seminal definition. In-order to assess the collective skills it becomes imperative to identify role competency requirements \& then measure the existing employee's competencies so that they can be compared to identify the existing gap \& thus lead to various suitable HR interventions.

Individual competencies can be thought of as the state or quality of being well qualified to perform a task. This term was coined by Mc-Cleland in 1973. A person gains competency through education, training, experience, or natural abilities. Klemp (1980, p21) defined competence as "an underlying characteristic of a person which results in effective and/or superior performance on the job." While a more detailed definition is "a cluster or related knowledge, skills, and attitudes that reflects a major portion of one's job (a role or responsibility), that correlates with performance on the job, that can be measured with well-accepted standards, and that can be improved with training and development (Parry, 1996, p50)."

As per the various researches it has been concluded that firms with superior SCM competency would demonstrate higher levels of shareholder value than their industry averages. This research work advances current understanding of Supply Chain Management's influence on performance of the firm and identifies various competencies metrics that appear to differentiate top SCM performers. The analysis of linkages between SCM competency \& the employee's perception of their relevance for capital goods industry should help managers to better appreciate the strategic, operational and financial advantages of developing SCM competency. The researchers believe that the additional insight gained from this assessment helps firms to more effectively direct scarce human resources competencies towards more proficient management of the supply chain processes that consume the majority of firm revenue $\&$ thus create a competitive advantage.

Accenture Consulting (2010) spells out three specific types of supply chain knowledge:

- Functional Knowledge, such as statistics, network dynamics and production optimization.

- Industry Knowledge, such as customer demand patterns, product lifecycles and material controls.

- Internal Company Knowledge, such as legacy systems, inventory strategies and company policies.

\section{OBJECTIVE/RESEARCH GAP}

Ample researches surveys have been attempted in various areas like Food processing industry, IT industry, Retail industry, Automobile industry but there is dearth of researches in the area of heavy engineering industry/ Capital goods industry. Out of 3 major issues that need attention the aspect of inappropriate competency levels was a major highlight of the Recommendations given during the 12 annual plan reports by the department of Capital Goods \& Engineering Sector. This proves that competency management should be considered as a focus area providing solution to the grilling problem. 
Around 1250 Crores is being sanctioned to BHEL for the attainment of Advanced Ultra Supercritical Technology. In general Engineering sector has been proposed to get a fund of 100 crores for skill development according to the Recommendations for 12th Five Year Plan for Capital Goods \& Engineering Sector.

Keeping the above information in mind this study is conducted with the following objectives:

1) Developing Preliminary \& Elaborated competency Profile for SCM Professionals

2) Identifying the critical competencies in Supply chain Management.

3) Creating Competency Map for SCM Professionals

\section{METHODOLOGY}

This is an Exploratory study using both Primary \& secondary database.

The Primary data is collected through qualitative research method like interview \& focus groups being conducted with the various supply chain management professionals positioned at different levels \& cross section of SCM in the local setups \& some of the leading players GE, BHEL, Alstom, Dresser-Rand, DOOSAN.

The data collected from secondary sources are from Internet, Books, and Magazines etc. The research is conducted in two parts. The first part of this study aimed at developing a competence profile for supply chain management professionals, by identifying competency elements based on literature review. This led to the creation of a preliminary competence profile \& then creating Elaborated competency Profile on the basis of the validation of competencies done by the various focus group studies.

\section{DATA ANALYSIS \& FINDINGS}

The list of requisite competencies is developed a result of extensive literature review from various sources \& Models like: APIC Model, Accenture's Core competency window model \& other competency dictionaries as depicted in Fig 1.

The Steps leading to the creation of Validated Elaborated competency profile for Supply Chain Management are as

1. The identified skills required for SCM function are listed against the principal components of the function as depicted in Fig 1 for (Preliminary Competence Profile).

2. The function is therefore broken down into a series of competency clusters

3. These competency clusters are then broken down into sub-components - referred as competency titles (which are the definitions of the skills and knowledge are provided).

4. Each definition is supplemented by a competency description which summarises the scope of the competency defined.

5. Elaborated Competency Profile is developed that specifies the requirement of various roles.

6. Competency Maps are created for each Competency Title to specify the knowledge \& Skills required for each title so that it can be mapped to the individuals.

Figure 1 provides the Preliminary Competence Profile -which is a compilation of competencies identified on the basis of literature review, categorised as Functional Competencies \& Managerial Competencies, then the functional competencies of the division are further categorised as core competencies \& associated competencies.

It is depicted in Fig: 2 which provides the various definition of the competency Taxonomy, Fig: 3 that defines the levels $\&$ their description, Fig: 4 that further explains the connect between the various roles \& the positions along with Fig: 5 providing the final Validated Elaborate critical competency Profiles for different Occupational (O) roles in various clusters attained as a result of focus group used in this dictionary.

A full complete detailed Sample Competency Map with description statement of the knowledge \& skills required under the competency title -departmental policies \& procedures of the competency Cluster -Legislative environment is being displayed in Fig 6.This is a final document that will help map the individual employees for this competency titles. Similar maps will be prepared for the rest of the titles in-order to map the SCM Professionals.

The competencies in Fig 1 are defined as:

a) Functional Competencies- These include technical competencies that are essential to perform a specific job in the organization within a defined technical or functional area of work, such as engineering calculations, mechanical drawing, and tool designing.

b) Managerial Competencies- These include 'soft' skills that enable a person to perform well in any function, such as communicating effectively, achieving tangible results and creative problem solving. These are generic because they can be applied to a variety of different functions and technical specialties. 
c) Associated Competencies - These include technical competencies in which incumbents need to possess basic awareness to be able to perform the assigned responsibilities effectively. The incumbent may not be proficient or technically expert in these competencies but will exhibit basic understanding of terms and processes.

Fig: 1- List of Functional Competencies \& Managerial Competencies for SCM Professionals

\begin{tabular}{|c|c|c|}
\hline \multicolumn{3}{|c|}{ Functional Competencies } \\
\hline \multicolumn{2}{|c|}{ Core Competencies } & Associated Competencies \\
\hline 1. & Negotiation Skills & 1. International Certifications \\
\hline 2. & Industrial HSE Practices & 2. Inventory Management \\
\hline 3. & General manufacturing processes & 3. Material Logistics Planning \\
\hline 4. & Product Knowledge & 4. Product Packaging Knowledge \\
\hline 5. & Special processes & 5. Financial Acumen \\
\hline 6. & Knowledge of Raw Material s & 6. Machine Capabilities \& plant Capacities \\
\hline 7. & Planning, Scheduling, Execution \& Control. & 7. Engineering Calculations \\
\hline 8. & Project Management Skills & 8. Industrial Utilities Operations \\
\hline 9. & Supplier Quality Assurance & 9. Tooling and Fixtures \\
\hline \multirow[t]{2}{*}{10.} & Cost Estimation & 10. Industrial Utilities Operations \\
\hline & & 11. Tooling and Fixtures \\
\hline \multicolumn{3}{|c|}{ Managerial Competencies } \\
\hline 1. & Analytical Abilities & 4. People Development \\
\hline 2. & Problem Solving & 5. Process Orientation \\
\hline 3. & Research Acumen & \\
\hline
\end{tabular}

This developed preliminary competence profile was validated \& expanded with the help of qualitative research- consisting of explorative interviews and focus group discussions conducted with the Top management \& middle management members of the case study organizations. This part of study aimed at expanding the preliminary competence profile, by identifying the activities and competency elements based on qualitative data. The preliminary competence profile was used as a framework to classify the data received from literature review and add information to the preliminary profile on the basis of qualitative information retrieved from focus groups \& interviews conducted to the various supply chain management professionals positioned at different levels \& cross section of SCM from the chosen organizations- GE, BHEL, Alston, Dresser-Rand, DOOSAN .This resulted in an elaborated competence profile/Competency Dictionary \& establishing connect between different competencies \& the required Knowledge \& skills according to the different roles.

Fig: 2- Definition of the Competency Taxonomy,

\begin{tabular}{|l|l|}
\hline Description & Definition \\
\hline Competency Cluster & High Level segment of the function \\
Competency Title & A short description defining the specific competency title \\
Competency Definition & A brief description of the competency title \\
Skills Requirement & Statement of the skills required within each occupational role competency title \\
Specific Knowledge requirement & Specific Knowledge requirements are noted that are directly related to \\
& a particular competency Title \\
\hline
\end{tabular}


Fig: 3-Defines the Levels \& their description

\begin{tabular}{|l|l|}
\hline & \multicolumn{1}{|c|}{ Knowledge Descriptors } \\
\hline Knowledge Level 1 & Requires a working knowledge with a practical understanding applied in straight \\
Knowledge Level 2 & forward circumstances \\
& Requires a working knowledge with a good understanding applied in \\
Knowledge Level 3 & circumstances of limited complexity \\
& Requires a thorough knowledge with an in-depth understanding applied in \\
Knowledge Level 4 & complex circumstances \\
& Requires a expert knowledge with a comprehensive understanding to be applied \\
& in highly complex circumstances \\
\hline
\end{tabular}

Fig: 4- Explains the Connect between the various roles \& the positions

\begin{tabular}{|l|l|}
\hline & \multicolumn{1}{|c|}{ Role Descriptors } \\
\hline Role Descriptors & Examples of relevant Positions \\
Role 1- Administrative & - SCM Clerk \\
Role 2- Technical & - SCM Practitioner \\
Role 3-Supervisory (Tactical) & - Assistant SCM Manager \\
& - Deputy Director (SCM Manager) \\
Role 4- Managerial (strategic) & - Director (Senior Manager) \\
& - Chief Director \\
& - Deputy Director General \\
\hline
\end{tabular}

Fig: 5 Validated Elaborate critical competency Profiles for different Occupational (O) roles in various clusters

\begin{tabular}{|c|c|c|c|c|c|c|c|}
\hline o & $\begin{array}{l}\text { Competency } \\
\text { Clusters }\end{array}$ & $\begin{array}{l}\mathrm{S} \\
\mathrm{N} \\
\mathrm{O}\end{array}$ & Competency Titles & $\begin{array}{l}\text { O. } \\
\text { Role } \\
1\end{array}$ & $\begin{array}{l}\text { O. } \\
\text { Role } \\
2\end{array}$ & $\begin{array}{l}\text { O. } \\
\text { Role } \\
3\end{array}$ & $\begin{array}{l}\text { O. } \\
\text { Role } \\
4\end{array}$ \\
\hline \multirow[t]{4}{*}{$\mathrm{A}$} & \multirow{4}{*}{ 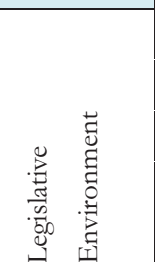 } & 1 & Legislative regulatory framework & $\sqrt{ }$ & $\sqrt{ }$ & $\sqrt{ }$ & $\sqrt{ }$ \\
\hline & & 2 & Departmental policies and procedures & $\sqrt{ }$ & $\sqrt{ }$ & $\sqrt{ }$ & $\sqrt{ }$ \\
\hline & & 3 & Industrial HSE Practices & $\sqrt{ }$ & $\sqrt{ }$ & $\sqrt{ }$ & $\sqrt{ }$ \\
\hline & & 4 & Strategy Development and Application & $\sqrt{ }$ & $\sqrt{ }$ & $\sqrt{ }$ & $\sqrt{ }$ \\
\hline \multirow[t]{5}{*}{$\mathrm{B}$} & \multirow{5}{*}{ 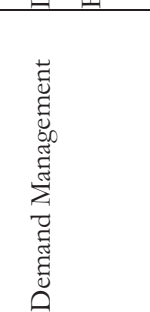 } & 1 & Needs Analysis & $\sqrt{ }$ & $\sqrt{ }$ & $\sqrt{ }$ & $\sqrt{ }$ \\
\hline & & 2 & Funding & & & $\sqrt{ }$ & \\
\hline & & 3 & $\begin{array}{l}\text { Compilation of specifications and/or } \\
\text { terms of reference }\end{array}$ & $\sqrt{ }$ & $\sqrt{ }$ & $\sqrt{ }$ & $\sqrt{ }$ \\
\hline & & 4 & Financial Acumen & & $\sqrt{ }$ & $\sqrt{ }$ & \\
\hline & & 5 & Performance trade-offs & & & $\sqrt{ }$ & $\sqrt{ }$ \\
\hline
\end{tabular}




\begin{tabular}{|c|c|c|c|c|c|c|c|}
\hline \multirow[t]{17}{*}{$\mathrm{C}$} & \multirow{17}{*}{ 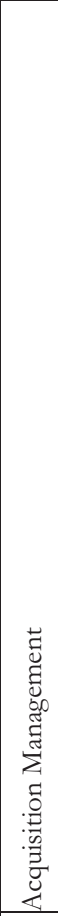 } & 1 & Compilation of bid documentation & $\sqrt{ }$ & $\sqrt{ }$ & $\sqrt{ }$ & $\sqrt{ }$ \\
\hline & & 2 & Receipt and opening bids & $\sqrt{ }$ & $\sqrt{ }$ & $\sqrt{ }$ & $\checkmark$ \\
\hline & & 3 & Evaluation and adjudication of & $\sqrt{ }$ & $\sqrt{ }$ & $\sqrt{ }$ & $\sqrt{ }$ \\
\hline & & 4 & Knowledge of Raw Materials & & $\sqrt{ }$ & $\sqrt{ }$ & $\sqrt{ }$ \\
\hline & & 5 & $\begin{array}{l}\text { Analysis of procurement requests for } \\
\text { quotations }\end{array}$ & $\sqrt{ }$ & $\sqrt{ }$ & $\sqrt{ }$ & $\sqrt{ }$ \\
\hline & & 6 & Sourcing suppliers for quotations & $\sqrt{ }$ & $\sqrt{ }$ & $\sqrt{ }$ & $\sqrt{ }$ \\
\hline & & 7 & Execution, Planning, Scheduling Control & $\sqrt{ }$ & $\sqrt{ }$ & $\sqrt{ }$ & $\sqrt{ }$ \\
\hline & & 8 & Strategy Development and Application & $\sqrt{ }$ & $\sqrt{ }$ & $\sqrt{ }$ & $\sqrt{ }$ \\
\hline & & 9 & Handling urgent and emergency cases & $\sqrt{ }$ & $\sqrt{ }$ & $\sqrt{ }$ & $\sqrt{ }$ \\
\hline & & 10 & InventoryManagement & $\sqrt{ }$ & $\sqrt{ }$ & $\sqrt{ }$ & \\
\hline & & 11 & Machine Capabilities \& plant Capacities & $\sqrt{ }$ & $\sqrt{ }$ & $\sqrt{ }$ & $\sqrt{ }$ \\
\hline & & 12 & Engineering Calculations & $\sqrt{ }$ & $\sqrt{ }$ & $\sqrt{ }$ & \\
\hline & & 13 & Industrial Utilities Operations & $\sqrt{ }$ & $\sqrt{ }$ & $\sqrt{ }$ & $\checkmark$ \\
\hline & & 14 & ProductPackagingKnowledge & & $\sqrt{ }$ & $\sqrt{ }$ & $\sqrt{ }$ \\
\hline & & 15 & ProductKnowledge & $\sqrt{ }$ & $\sqrt{ }$ & $\sqrt{ }$ & $\checkmark$ \\
\hline & & 16 & Tooling and Fixtures & $\sqrt{ }$ & $\sqrt{ }$ & $\sqrt{ }$ & \\
\hline & & 17 & Specialprocesses & $\sqrt{ }$ & $\sqrt{ }$ & $\sqrt{ }$ & $\sqrt{ }$ \\
\hline $\mathrm{D}$ & & 1 & Contract Administration & $\sqrt{ }$ & $\sqrt{ }$ & $\sqrt{ }$ & $\sqrt{ }$ \\
\hline & & 2 & Supplier Performance & $\sqrt{ }$ & $\sqrt{ }$ & $\sqrt{ }$ & $\checkmark$ \\
\hline & 芑 & 3 & Contract Management & $\sqrt{ }$ & $\sqrt{ }$ & $\sqrt{ }$ & $\checkmark$ \\
\hline & $\underset{D}{0}$ & 4 & Supply Chain synchronisation & $\sqrt{ }$ & $\sqrt{ }$ & $\sqrt{ }$ & \\
\hline & $\stackrel{\text { Iี }}{\Sigma}$ & 5 & Performance trade-offs & & $\checkmark$ & $\checkmark$ & $\checkmark$ \\
\hline & $\underset{\widetilde{c}}{\breve{U}}$ & 6 & Negotiation Skills & $\sqrt{ }$ & $\sqrt{ }$ & Y & $\sqrt{V}$ \\
\hline & ن & 7 & General manufacturing processes & & $\sqrt{ }$ & $\sqrt{ }$ & $\sqrt{ }$ \\
\hline & & 8 & International Certifications & $\sqrt{ }$ & $\sqrt{ }$ & $\sqrt{ }$ & \\
\hline $\mathrm{E}$ & & 1 & Requisition of goods and services. & $\sqrt{ }$ & $\sqrt{ }$ & $\sqrt{ }$ & $\checkmark$ \\
\hline & & 2 & Placing orders & $\sqrt{ }$ & $\sqrt{ }$ & $\sqrt{ }$ & $\checkmark$ \\
\hline & & 3 & Receiving goods & $\sqrt{ }$ & $\sqrt{ }$ & $\sqrt{ }$ & \\
\hline & & 4 & Goods distribution & $\sqrt{ }$ & $\sqrt{ }$ & $\sqrt{ }$ & \\
\hline & & 5 & Warehouse management & $\sqrt{ }$ & $\sqrt{ }$ & $\sqrt{ }$ & $\checkmark$ \\
\hline & & 6 & Stock taking & $\sqrt{ }$ & $\sqrt{ }$ & $\sqrt{ }$ & $\checkmark$ \\
\hline & & 7 & Matching documentation & & $\sqrt{ }$ & $\sqrt{ }$ & $\checkmark$ \\
\hline & & 8 & Preparation of payment documentation & $\checkmark$ & $\checkmark$ & $\sqrt{ }$ & $\sqrt{ }$ \\
\hline & & 9 & Distribution & & $\sqrt{ }$ & $\sqrt{ }$ & \\
\hline & & 10 & Locating facilities & $\checkmark$ & $\checkmark$ & $\sqrt{ }$ & \\
\hline & & 11 & Warehousing & $\sqrt{ }$ & $\checkmark$ & $\sqrt{ }$ & $\checkmark$ \\
\hline & & 12 & Warehouse management & $\sqrt{ }$ & $\sqrt{ }$ & $\sqrt{ }$ & $\checkmark$ \\
\hline
\end{tabular}




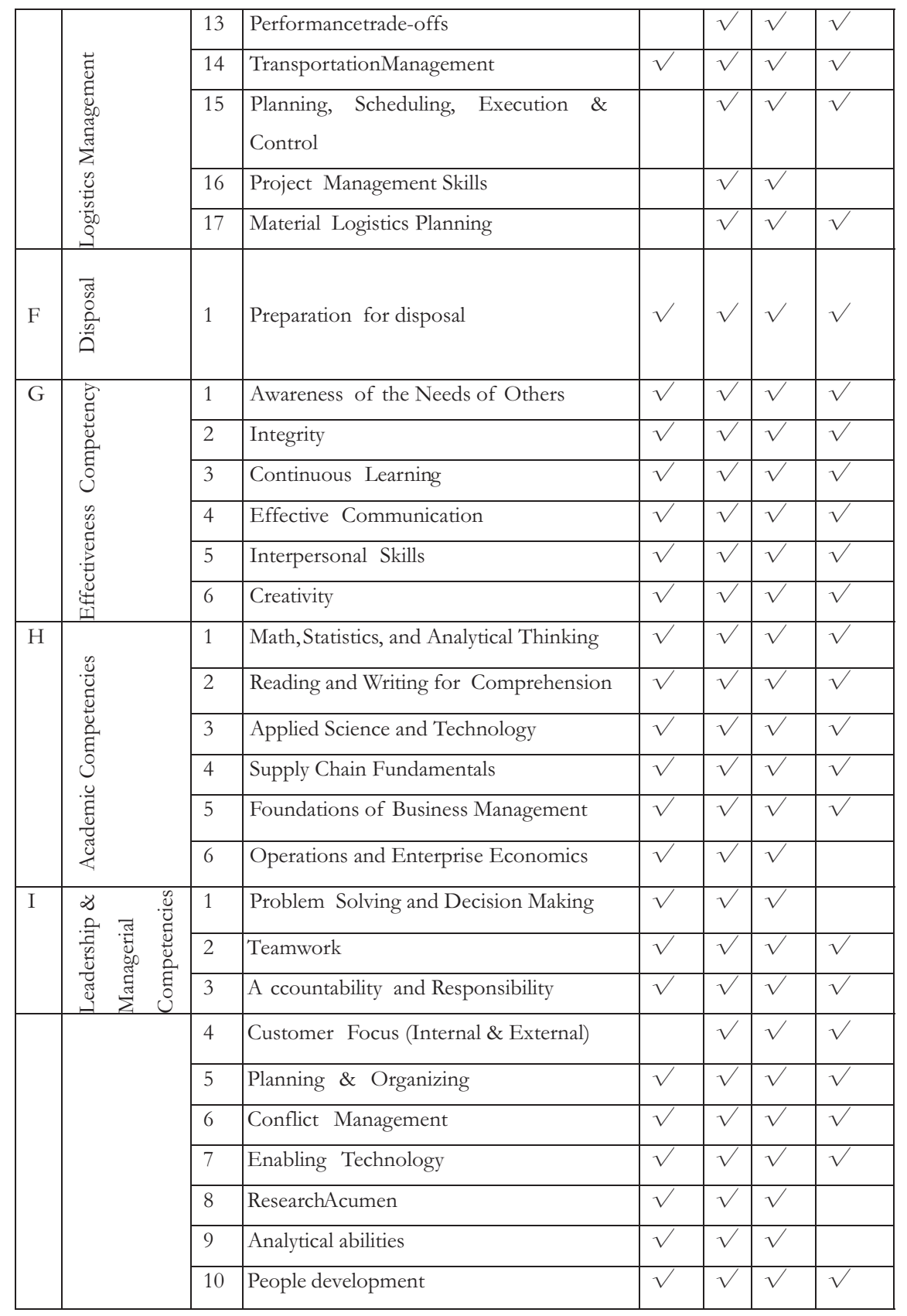


Fig 6 - Competency Map for the Title-Legislatory Regulatory Framework :

\begin{tabular}{|c|c|c|c|c|}
\hline $\begin{array}{l}\text { Competency } \\
\text { Cluster }\end{array}$ & \multicolumn{4}{|l|}{ Legislative Environment } \\
\hline Competency Title & \multicolumn{4}{|c|}{ Departmental Policies \& Procedures } \\
\hline $\begin{array}{l}\text { Competency } \\
\text { Definition }\end{array}$ & \multicolumn{4}{|c|}{ This is the ability to develop \& implement departmental policies \& Procedures } \\
\hline $\begin{array}{l}\text { Specific } \\
\text { Knowledge } \\
\text { Requirement }\end{array}$ & $\begin{array}{l}\text { Occupational } \\
\text { Role } 1\end{array}$ & $\begin{array}{l}\text { Occupational } \\
\text { Role } 2\end{array}$ & $\begin{array}{l}\text { Occupational } \\
\text { Role } 3\end{array}$ & $\begin{array}{l}\text { Occupational } \\
\text { Role } 4\end{array}$ \\
\hline $\begin{array}{l}\text { Departmental } \\
\text { Policies \& } \\
\text { Procedures } \\
\text { Delegation of } \\
\text { Authority } \\
\text { Principles of } \\
\text { Internal control }\end{array}$ & $\begin{array}{l}\text { Requires a working } \\
\text { Knowledge with a } \\
\text { practical } \\
\text { understanding to be } \\
\text { applied in a straight } \\
\text { forward } \\
\text { circumstances }\end{array}$ & $\begin{array}{l}\text { Requires a working } \\
\text { Knowledge with a } \\
\text { practical } \\
\text { understanding to be } \\
\text { applied in } \\
\text { circumstances of } \\
\text { internal ambiguity }\end{array}$ & $\begin{array}{l}\text { Requires a thorough } \\
\text { Knowledge with an } \\
\text { in-depth } \\
\text { understanding to be } \\
\text { applied in complex } \\
\text { circumstances }\end{array}$ & $\begin{array}{l}\text { Requires an expert } \\
\text { Knowledge with an } \\
\text { comprehensive } \\
\text { understanding to be } \\
\text { applied in a highly } \\
\text { complex } \\
\text { circumstances }\end{array}$ \\
\hline \multirow[t]{2}{*}{$\begin{array}{l}\text { Skill } \\
\text { Requirements }\end{array}$} & $\begin{array}{l}\text { This incumbent } \\
\text { should be able to }\end{array}$ & $\begin{array}{l}\text { This incumbent } \\
\text { should be able to }\end{array}$ & $\begin{array}{l}\text { This incumbent } \\
\text { should be able to }\end{array}$ & $\begin{array}{l}\text { This incumbent } \\
\text { should be able to }\end{array}$ \\
\hline & $\begin{array}{l}\text { Perform SCM } \\
\text { activities in } \\
\text { compliance with } \\
\text { Departmental Policies } \\
\text { \& Procedures }\end{array}$ & $\begin{array}{l}\text { Perform SCM } \\
\text { activities in } \\
\text { compliance with } \\
\text { Departmental } \\
\text { Policies \& } \\
\text { Procedures }\end{array}$ & $\begin{array}{l}\text { Monitor the } \\
\text { performance of } \\
\text { SCM activities in } \\
\text { compliance with } \\
\text { Departmental } \\
\text { Policies \& } \\
\text { Procedures }\end{array}$ & $\begin{array}{l}\text { Manage the } \\
\text { performance of } \\
\text { SCM activities in } \\
\text { compliance with } \\
\text { Departmental } \\
\text { Policies \& } \\
\text { Procedures }\end{array}$ \\
\hline
\end{tabular}

Out of this validated industry profile the researchers further attempted to explore the critical Industry specific competencies which are mandatory to the successful contribution of SCM in the present cut throat competitive \& dynamic business environment.

For it the focus group was further probed to identify the critical competencies for SCM professionals. The analysis resulted in segregating Technical Skills as critical competencies at the initial level till the starting 5 to 8 years of the career (Occupational Level 2) \& after that the critical distinctive competencies were from the leadership \& Managerial competencies cluster (Operational Level 3 \& 4).

\section{CONCLUSION}

The supply chain management concept has grown and matured over the last decade due to globalization and has infused varied competencies across this industry as it will continue to evolve in the similar business model diverging across the globe.

The critical competencies for Occupational Role $1 \& 2$, is focused on the various technical skills such as engineering calculations, manufacturing site operations, Contract management \& inventory management, competence of meeting global norms and compliances but under a process of time it gives place to the behavioral skills like customer focus, analytical abilities, conflict resolution, excellent communication skills, business acumen, finance and commercial negotiating skills etc for the higher level roles. As per the general trend most personnel keep working in the similar industry sector throughout of their career and nurture the technical competencies over a period of time. 
They have the command on product and market knowledge of own and competitor's as well \& hence the professionals who are able to hone their leadership \& people skills are able to create a distinctive place for themselves $\&$ attain success.

As per the findings the critical distinctive skill set is focused more on generic and managerial as compared to technical aspects such as Process orientation, Analytical and problem solving skills, Team work \& coordination, People development. The results help to provide greater understanding of key competencies of the leading professionals and set benchmark for the growing organizations and younger aspirants for future leadership in the area of supply chain management.

\section{FUTURE SCOPE/ LIMITATIONS}

The research can be extended to larger number of companies in Capital goods industry or further comparative analysis can be conducted for the supply chain management professionals in different industries or at different location of the world.

It also contributes to the area of HR function in defining competencies for recruitment \& selection, staff training and development, performance management. The analysis can be utilized by them to further develop, retain \& lead talented supply chain management professionals through the route of succession planning.

The research is limited to the five organisations in India only hence the identified set of critical competencies of Supply chain professionals cannot be considered to be universally justified. It may vary due to organization specificity, country specificity etc. Though it may not completely apply but the core competencies which are not affected by organizational \& country dimensions will still hold true throughout the world. The research is based on the well known organizations with established practices \& great results \& thus holds credential. It will be useful for business managers to understand and implement supply chain management plans in terms of their importance and the company's culture.

Also this study has not delved on the other initiatives that can contribute to the effectiveness of SCM professionals like the Skill Development initiatives done by National Skill Development Council and Directorate General of Employment and Training (DGET) are the two major funding agencies for skill development. New initiatives like the implementation of Automobile Skill Development Council \& other proposed councils with the help of DGET by the Department of Heavy Industry. Similar councils are proposed for the Capital Goods and Engineering Sector. Certain other practices that can strengthen the skill set of employees like developing linkages with local SEZs, EPZs, knowledge parks, polytechnic, industry chambers to develop skill development clusters, $100 \%$ finance support for micro enterprise for technology up gradation, developing centre of excellence for training of trainers, upgrade ITI.

\section{BIBLIOGRAPHY \& REFERENCES}

1. "APICS Supply chain manager-Competency Model" (2009), the association of operations management. (Online), Available: APICS Supply chain managerCompetency Model.pdf.

2. Closs, David J. (2000), "Preface," Journal of Business Logistics, Vol. 21, No. 1, p. I.

3. Cooper, Martha C, Douglas M. Lambert, and Janus D. Pagh (1997), "Supply Chain Management: More than a New Name for Logistics," International Journal of Logistics Management, Vol. 8, No. 1, pp. 1-14.

4. Department of heavy Industry Ministry of heavy industries \& public enterprises (2011), "Report of the working group on Capital goods \& Engineering sector", Recommendation for $12^{\text {th }}$ five year plan annual plan for Capital goods \& Engineering sector report., \{Online ), Available:supply-chain-survey-report-2010100119150437-phpapp02.pdf.

5. Department National Treasury, Republic of South Africa, (2012), "Supply Chain management", Africa.

6. Ellinger, A.E. etal (2010), "The Influence of Supply Chain Management Competency on Customer Satisfaction and Shareholder Value", Society for Marketing Advances Proceedings.

7. Ellinger, A.E. etal (2011), "Supply Chain Management Competency and Firm Financial Success", Journal of business Logistics,2011,. 32(3): 214-226.

8. Giunipero, Larry C. and Dawn H. Pearcy (2000), "World-Class Purchasing Skills: An Empirical Investigation," Journal of Supply Chain Management, Vol. 36, No. 4, pp. 4-13.

9. Gammelgaard, B. etal, (2001), "Logistics skills and competencies for supply chain management", Journal of business logistics, Vol.22, No. 2, 200127.

10. Hammer, M.(2004), "Deep Change: How operational Innovation can transform your company", Harvard Business Review, April 2004.

11. Kay, J. (1993),'The structure of strategy", Business Strategy review, June 1993.

12. Prahalad, K. C. (1990),'"The Core Competence of the corporation", Harvard Business Review, May-June 1990 issue. 
13. Sanghi, S. (2007),'The Handbook of Competency Mapping: Understanding, Designing and Implementing competency Models in organizations”, Sage Publications.

14. Wallenberg C.M. 2010, RIRL (2010), "The Competence differences at the logistics \& sales", The $8^{\text {th }}$ International Conference on logistics \& SCM Research, Bordeaux Management School.

\section{WEBSITE LINKS}

1. Http://www.propertyinsurancecoveragelaw.com/ uploads/file/supply-chain-survey-2011.pdf

2. Http://www.accenture.com/sitecollectiondocuments/ pdf/282accenture_core_competency_20_the_case_for_ outsourcing_supply_chain_management.pdf

3. Http://tntp.org/assets/tools/KIPP_Leadership_ Framework_and_Competency_Model_FINAL.pdf

4. http:// www.investopedia.com/terms /h/heavy_industry.asp

5. http://www.capgemini-consulting.com/think/pointsof-view/2012-global-supply-chain-agenda/ 